\title{
Studies on the Rain Scavenging Process of Tritium in a Tropical Site at Narora in India
}

\author{
Y. P. Gautam, ${ }^{1}$ Saivajay Sharma, ${ }^{1}$ A. K. Sharma, ${ }^{1}$ Aviansh Kumar, ${ }^{1}$ \\ P. M. Ravi, ${ }^{2}$ and P. K. Sarkar ${ }^{2}$ \\ ${ }^{1}$ Environmental Survey Laboratory, Environmental Studies Section, Health Physics Division, Bhabha Atomic Research Centre, \\ Narora Atomic Power Station, Narora, Bulandshahr 202389, India \\ ${ }^{2}$ Health Physics Division, Bhabha Atomic Research Centre, Mumbai 400 085, India
}

Correspondence should be addressed to Y. P. Gautam; ypgautam@npcil.co.in

Received 4 December 2012; Accepted 5 February 2013

Academic Editor: Karnam Ramakumar

Copyright (C) 2013 Y. P. Gautam et al. This is an open access article distributed under the Creative Commons Attribution License, which permits unrestricted use, distribution, and reproduction in any medium, provided the original work is properly cited.

\begin{abstract}
This study presents the results of systematic experiments on tritium $\left({ }^{3} \mathrm{H}\right)$ concentrations in ground level air against those in rainwater near a pressurized heavy water reactor in a tropical region. The samples were collected over the rainy season of year 2011 from eight locations in the environment around Narora Atomic Power Station. The specific activity ratio of ${ }^{3} \mathrm{H}$ between rainwater and air moisture at ground level was calculated for each data set. The average specific activity ratio was found to be ranged from 0.12 to 1.1. A correlation $\left(r^{2}=0.62\right.$ to $\left.0.76, P<0.001\right)$ was observed between the total rain hours in a day and the rainwater ${ }^{3} \mathrm{H}$ activity. Higher rain duration with slower rain rate yielded higher ${ }^{3} \mathrm{H}$ concentrations as more time was available for the scavenging/wash-out process to take effect together with lower dilution. Annual tritium (HTO) wet deposition has been measured and calculated for the year 2011 within $0.8 \mathrm{~km}$ distance from $145 \mathrm{~m}$ high stack of Narora Atomic Power Station (NAPS) at nine locations in different directions. The range of deposition velocity, $V_{w}\left(\mathrm{~m} \cdot \mathrm{s}^{-1}\right)$, at nine locations for the years 2011 is found to be from $4.43 E-04$ to $6.42 E-03$. The average value for wet deposition velocity $V_{w}$ for NAPS site is estimated as $3.17 E-03 \mathrm{~m} \cdot \mathrm{s}^{-1}$.
\end{abstract}

\section{Introduction}

Tritium $\left({ }^{3} \mathrm{H}\right)$ is one of the major long-lived radioisotopes in the gaseous effluent released from any Pressurized Heavy Water Reactor (PHWR). Tritium produced in a PHWR is released into the atmosphere in the form of tritiated water vapour (HTO) [1]. Because of its physicochemical similarity with water, HTO is incorporated in all environmental matrices such as soil, air, and biota. In order to carry out an impact assessment due to ${ }^{3} \mathrm{H}$, it is necessary to understand the kinetics of transfer of ${ }^{3} \mathrm{H}$ through the various environmental matrices. The process of ${ }^{3} \mathrm{H}$ removal from the atmosphere is by either wet or dry deposition [2]. When raindrops pass vertically through an HTO plume, rainwater scavenges ${ }^{3} \mathrm{H}$ from the air due to a wash-out process. Scavenging by rain is one of the phenomena which transfers substances present in the atmosphere to the ground. It consists of two steps, known as in-cloud scavenging (rain out) and below cloud scavenging (wash out) [3]. Scavenging ratios represent the vertical scavenging efficiencies of transfer from the atmosphere to rainwater. Velarde and Perlado [4] reported that wet deposition is critical for the incorporation of tritiated water vapour into the natural biological chain. It has been reported that the wash-out coefficient of ${ }^{3} \mathrm{H}$ depends upon the distance from the source, atmospheric stability, air temperature, and so forth [5]. The process of washout of ${ }^{3} \mathrm{H}$ due to precipitation is quite different from that of particulate matter (radionuclides) such as ${ }^{90} \mathrm{Sr}$ and ${ }^{137}$ Cs. It is reported that rain scavenging of particulates is an irreversible process while that of ${ }^{3} \mathrm{H}$ is reversible [6]. The theory of washout of gaseous pollutants from the atmosphere was first comprehensively applied to tritiated water (HTO) vapour by Hales $[7,8]$. Using a gas scavenging model, the wash out of tritiated water from an atmospheric plume emitted from a $60 \mathrm{~m}$ stack was calculated by Dana et al. [9] and Abrol [6]. Many assumptions, such as raindrops 
being spherical, that their size remains constant during a downfall, that they fall vertically with a constant velocity, and so forth are made during any theoretical evaluation of ${ }^{3} \mathrm{H}$ concentration in rainwater. Satisfaction of all of these assumptions is unlikely. Hence, the modelled value can be very dissimilar to the actual value. There should be an attempt to analyze experimentally observed values of ${ }^{3} \mathrm{H}$ activity in rainwater to better understand the parameters influencing the ${ }^{3} \mathrm{H}$ wash-out process. The range of ${ }^{3} \mathrm{H}$ emission from Narora Atomic Power Station during study period was 103.6 to $584.6 \mathrm{~GB} \mathrm{qd}^{-1}$ with an average $196.4 \mathrm{~GB} \mathrm{qd}^{-1}$.

Belovodski et al. [10] studied the kinetics of wash-out tritium oxide (HTO) from air by water drops under laboratory conditions. Nankar et al. [11] carried out a comprehensive study on the deposition characteristics at Kakrapar site in central western and off the coast part of India, and Reji et al. [12] carried out similar studies at Kaiga site south west and off the coast of India. Similar studies have not been conducted in north central part of India which is climatically quite different as compared to Kakrapar and Kaiga sites. This study presents the measured ${ }^{3} \mathrm{H}$ activity in air moisture and in rainwater collected at ground level near a PHWR. The samples were collected over the rainy season of year 2011 from nine different locations within NAPS site. Each data set contains ${ }^{3} \mathrm{H}$ activity in air, rainwater, and the corresponding meteorological parameters of wind speed, wind direction, Pasquill's stability category, atmospheric temperature, and relative humidity. The specific activity ratios, that is, the ratio of the specific activity of tritium in rainwater $\left(\mathrm{Bq} \cdot \mathrm{L}^{-1}\right)$ to that in air moisture $\left(\mathrm{Bq} \cdot \mathrm{L}^{-1}\right)$, were calculated for each data set. A total of 22 data sets were collected and interpreted based on the theoretical information available in the literature.

\section{Experimental Procedures}

2.1. Site Description and Sample Collection. This study was carried out at the Narora Atomic Power Station (NAPS) site. It is an inland site situated on the right bank of Lower Ganga Canal (LGC) and Parallel Lower Ganga Canal (PLGC) at a distance of $3.5 \mathrm{~km}$ from Narora Barrage. The area of the plant site is fairly flat terrain with dense farming activities around the site. The site lies in Indo-Gangetic alluvium, bordered on the north by the Shivalic foothills, which is about $60 \mathrm{~km}$ away from Aligarh, Uttar Pradesh state, India (latitude $28^{\circ} 10^{\prime} 00^{\prime \prime}$ North and longitude $78^{\circ} 24^{\prime} 09^{\prime \prime}$ East). At NAPS, two pressured heavy water reactors (PHWRs) having capacity of each 220 MWe are operating since the year 1991. The average annual rainfall recorded at NAPS site during 1989-2011 is $890 \mathrm{~mm}$. Air moisture and rainwater samples were collected simultaneously from three locations within NAPS site. The sampling location is given in Figure 1. Air moisture was collected by a moisture condensation method [13], and rainwater was collected by spot sampling during the period of rain.

2.2. Estimation of ${ }^{3} \mathrm{H}$ Activity. An aliquot $(3 \mathrm{~mL})$ of the sample was mixed with $7 \mathrm{~mL}$ scintillator cocktail Di-IsopropylNaphthalene- (DIN-) based Ultima Gold LLT liquid scin- tillation solution and counted for ${ }^{3} \mathrm{H}$ using an ultra lowlevel Liquid Scintillation Spectrometer (LSS) system (model: TRICARB-3170 TR/SL). The counting system was calibrated using a ${ }^{3} \mathrm{H}$ standard supplied by Amersham International. The system background count rate was 1-2 counts per minute, and the counting efficiency for ${ }^{3} \mathrm{H}$ was about $25 \%$. Detection limits varied depending on sample type, counting time, and mass.

2.3. Meteorological Data Collection. Meteorological parameters such as wind speed, wind direction, stability category, atmospheric temperature, and relative humidity were collected using sensors installed on meteorological tower located at the site. The primary meteorological data were $1 \mathrm{~h}$ averaged values. Using a power law [14], wind characteristics were extended up to $145 \mathrm{~m}$.

2.4. Estimation of Wet Deposition Velocity. The measured ${ }^{3} \mathrm{H}$ concentration $\left(\mathrm{Bq} \cdot \mathrm{L}^{-1}\right)$ in daily rainwater at a sampling point was multiplied by rainfall $(\mathrm{mm})$ during the sampling period to determine deposition per unit area $\left(\mathrm{Bq} \cdot \mathrm{m}^{-2}\right)$ and summed up to evaluate annual ${ }^{3} \mathrm{H}$ surface loading due to rainfall. Wet deposition velocity of airborne activity due to rainfall (NCRPReport No. 76,1992) was calculated using the relation given by

$$
V_{w}=\frac{W}{\chi_{o}}\left(\mathrm{~m} \cdot \mathrm{s}^{-1}\right),
$$

where $V_{w}$ is the wet deposition velocity $\left(\mathrm{m} \cdot \mathrm{s}^{-1}\right) ; W$ is the wet flux $\left(\mathrm{Bq} \cdot \mathrm{m}^{-2} \cdot \mathrm{s}^{-1}\right) ; \chi_{o}$ is the surface level air concentration $\left(\mathrm{Bq} \cdot \mathrm{m}^{-3}\right)$.

\section{Results and Discussions}

3.1. Meteorological Characteristics of Sampling Location. Meteorological data such as wind speed, wind direction, stability, temperature, and humidity were recorded during the sampling events and are reported in Table 1 . The hourly average wind speed at $145 \mathrm{~m}$ (extrapolated from the measurement point at $30 \mathrm{~m}$; Faw and Shultis, [14]) during the sampling events varied from $1.42 \mathrm{~m} \mathrm{~s}^{-1}$ to $6.6 \mathrm{~m} \mathrm{~s}^{-1}$. In most events, the wind was observed to be in the SE sector and the stability category was $\mathrm{D}$. The atmospheric stability category was measured using the standard procedure using standard deviation of wind direction and wind speed at $10 \mathrm{~m}$ height. Figures 2(a) and 2(b) show the wind roses at $145 \mathrm{~m}$ height for 2011 during the rainy seasons and the overall wind rose across 2011. This figure represents the prevailing wind directions and the distribution of wind speed.

\subsection{Variation of ${ }^{3} H$ Activity in Air Moisture and Rainwater} Sample. Table 2 shows the activity of ${ }^{3} \mathrm{H}$ in air moisture and in rainwater collected during various days comprising single rain events at ground level. It was observed that the mean ${ }^{3} \mathrm{H}$ activity in air varied from 0.5 to $15.7 \mathrm{~Bq} \cdot \mathrm{m}^{-3}$ (equivalent to $35-992.4 \mathrm{~Bq} \cdot \mathrm{L}^{-1}$ of air moisture) and in rainwater varied from 14.2 to $124 \mathrm{~Bq} \cdot \mathrm{L}^{-1}$. For comparison, Miljević et al. [15] 
TABLE 1: Details of meteorological data at NAPS, Narora.

\begin{tabular}{|c|c|c|c|c|c|c|c|c|}
\hline $\begin{array}{l}\text { Sr. } \\
\text { number }\end{array}$ & $\begin{array}{c}\text { Date of } \\
\text { sampling }\end{array}$ & $\begin{array}{l}\text { Wind speed at } \\
145 \mathrm{~m}(\mathrm{~m} / \mathrm{sec})\end{array}$ & $\begin{array}{l}\text { Wind direction } \\
\quad \text { (Sector) }\end{array}$ & $\begin{array}{c}\text { P-G stability } \\
\text { class }\end{array}$ & Temperature $\left({ }^{\circ} \mathrm{C}\right)$ & $\begin{array}{c}\text { Relative } \\
\text { humidity (\%) }\end{array}$ & $\begin{array}{c}\text { Moisture } \\
\text { content } \\
\left(\mathrm{g} \mathrm{m}^{-3}\right)\end{array}$ & Total rain hours \\
\hline 1 & 23.07 .11 & 4.10 & $\mathrm{E}$ & $\mathrm{D}$ & 27 & 96 & 25.78 & 4 \\
\hline 2 & 27.07.11 & 2.23 & SE & $\mathrm{E}$ & 28.7 & 100 & 28.78 & 4 \\
\hline 3 & 28.07 .11 & 1.56 & SSE & $\mathrm{D}$ & 25.4 & 100 & 22.4 & 2 \\
\hline 4 & 05.08 .11 & 2.25 & SE & $\mathrm{D}$ & 33.6 & 100 & 37.61 & 1 \\
\hline 5 & 06.08 .11 & 1.42 & SSE & $\mathrm{D}$ & 27.4 & 86 & 25.78 & 5 \\
\hline 6 & 07.08.11 & 6.50 & SE & $\mathrm{D}$ & 29.6 & 90 & 30.38 & 2 \\
\hline 7 & 08.08 .11 & 3.24 & SSE & $\mathrm{D}$ & 27.1 & 96 & 25.78 & 7 \\
\hline 8 & 09.08.11 & 6.50 & SE & $\mathrm{D}$ & 29.7 & 81 & 30.38 & 1 \\
\hline 9 & 10.08 .11 & 6.58 & SE & $\mathrm{E}$ & 26.7 & 100 & 25.78 & 2 \\
\hline 10 & 11.08 .11 & 4.05 & NW & $\mathrm{D}$ & 29.4 & 90 & 28.78 & 3 \\
\hline 11 & 12.08 .11 & 5.47 & NNW & $\mathrm{D}$ & 26.7 & 99 & 25.78 & 3 \\
\hline 12 & 15.08 .11 & 3.40 & NNE & $\mathrm{E}$ & 27.0 & 99 & 25.78 & 5 \\
\hline 13 & 16.08 .11 & 3.22 & SSE & $\mathrm{D}$ & 26.8 & 99 & 25.78 & 5 \\
\hline 14 & 17.08 .11 & 3.37 & SE & $\mathrm{D}$ & 26.3 & 98 & 24.38 & 1 \\
\hline 15 & 19.08.11 & 4.18 & SE & $\mathrm{D}$ & 26.4 & 100 & 24.38 & 1 \\
\hline 17 & 23.08 .11 & 3.08 & SSE & $\mathrm{E}$ & 26.1 & 100 & 27.24 & 5 \\
\hline 18 & 25.08 .11 & 1.69 & $\mathrm{E}$ & $\mathrm{C}$ & 31.9 & 81 & 33.83 & 1 \\
\hline 19 & 27.08 .11 & 4.92 & $\mathrm{E}$ & $\mathrm{C}$ & 27.6 & 100 & 27.24 & 1 \\
\hline 20 & 03.09.11 & 5.80 & SE & $\mathrm{D}$ & 27 & 95 & 25.78 & 2 \\
\hline 21 & 08.09.11 & 1.60 & SE & $\mathrm{D}$ & 24 & 100 & 21.78 & 1 \\
\hline 22 & 09.09.11 & 3.37 & SE & $\mathrm{D}$ & 29 & 90 & 28.78 & 1 \\
\hline
\end{tabular}

TABLE 2: Activity of ${ }^{3} \mathrm{H}$ in air moisture and in rainwater samples.

\begin{tabular}{|c|c|c|c|c|c|c|c|}
\hline $\begin{array}{l}\text { Location, distance }(\mathrm{Km}) \text {, } \\
\text { and direction from NAPS }\end{array}$ & $\begin{array}{l}\text { Range of }{ }^{3} \mathrm{H} \text { in } \\
\text { rain }(\mathrm{Bq} / \mathrm{L})\end{array}$ & $\begin{array}{c}\text { Geometric } \\
\text { mean of }{ }^{3} \mathrm{H} \text { in } \\
\text { rain }(\mathrm{Bq} / \mathrm{L})\end{array}$ & $\begin{array}{c}\text { Average } \\
\text { moisture }{ }^{3} \mathrm{H} \\
\text { concentration } \\
\mathrm{Bq} / \mathrm{m}^{3}\left(\chi_{0}\right)\end{array}$ & $\begin{array}{c}{ }^{3} \mathrm{H} \text { surface } \\
\text { loading }(\mathrm{W}) \\
\left(\mathrm{Bq} / \mathrm{m}^{2} / \mathrm{sec}\right)\end{array}$ & $\begin{array}{c}\text { Average } \\
\text { deposition } \\
\text { velocity } \\
(\mathrm{m} / \mathrm{sec}) \\
\mathrm{W} / \chi_{0}\end{array}$ & $\begin{array}{c}\text { Average } \\
\text { moisture }{ }^{3} \mathrm{H} \\
\text { concentration } \\
(\mathrm{Bq} / \mathrm{L})\end{array}$ & $\begin{array}{c}\text { Specific } \\
\text { activity ratio }\end{array}$ \\
\hline SWMF, $0.61 \mathrm{~km}$, SSE & $12-356$ & 86.05 & 5.13 & $4.36 E-03$ & $8.48 E-04$ & 325.1 & 0.26 \\
\hline WMP Dyke, $0.65 \mathrm{~km}, \mathrm{SSE}$ & $10-496$ & 97.96 & 4.09 & $5.17 E-03$ & $1.26 E-03$ & 258.7 & 0.38 \\
\hline WMP Incr. $0.68 \mathrm{~km}$, SSE & $10-648$ & 124.04 & 15.71 & $6.97 E-03$ & $4.43 E-04$ & 992.4 & 0.12 \\
\hline HWM Dyke, 0.55 km, SE & $10-486$ & 47.89 & 3.14 & $3.77 E-03$ & $1.20 E-03$ & 210.0 & 0.23 \\
\hline $\begin{array}{l}\text { Radha Canteen, } 0.48 \mathrm{~km} \text {, } \\
\text { SE }\end{array}$ & $10-427$ & 14.80 & 0.71 & $1.74 E-03$ & $2.46 E-03$ & 53.4 & 0.28 \\
\hline Switch Yard $0.46 \mathrm{~km}, \mathrm{SW}$ & $10-457$ & 20.45 & 1.30 & $2.08 E-03$ & $1.60 E-03$ & 84.5 & 0.24 \\
\hline IDCT, $0.34 \mathrm{~km}, \mathrm{ENE}$ & $10-428$ & 40.03 & 0.45 & $2.89 E-03$ & $6.42 E-03$ & 35.3 & 1.13 \\
\hline Guard House, 0.44 km, NW & $10-465$ & 23.80 & 0.65 & $2.23 E-03$ & $3.43 E-03$ & 52.4 & 0.45 \\
\hline ESL, $0.8 \mathrm{~km}, \mathrm{WNW}$ & $10-193$ & 14.22 & 0.53 & $1.26 E-03$ & $2.38 E-03$ & 41.6 & 0.34 \\
\hline
\end{tabular}

reported annual mean ${ }^{3} \mathrm{H}$ concentrations in precipitation from 2.2 to $35.4 \mathrm{~Bq} \cdot \mathrm{L}^{-1}$ in the vicinity of the Vinca Institute of Nuclear Sciences, Yugoslavia. The maximum air ${ }^{3} \mathrm{H}$ activity at the NAPS site was observed on July 25 2011, and the maximum rainwater ${ }^{3} \mathrm{H}$ activity was observed on August 24 2011, at HWM dyke. It is to be noted that the maximum air ${ }^{3} \mathrm{H}$ activity was poorly correlated with the maximum rainwater ${ }^{3} \mathrm{H}$ activity. This can be attributed to the complexity of the wash-out process and the variation of the influencing parameters. The influence of total rain hours in a day on the rainwater ${ }^{3} \mathrm{H}$ activity was studied for all eight locations, and a correlation coefficient for total rain hours in a day on the rainwater ${ }^{3} \mathrm{H}$ activity ranging from 0.62 to $0.76(P<$ 0.001 ) was found (Figure 3 ). The duration of a rainfall event 


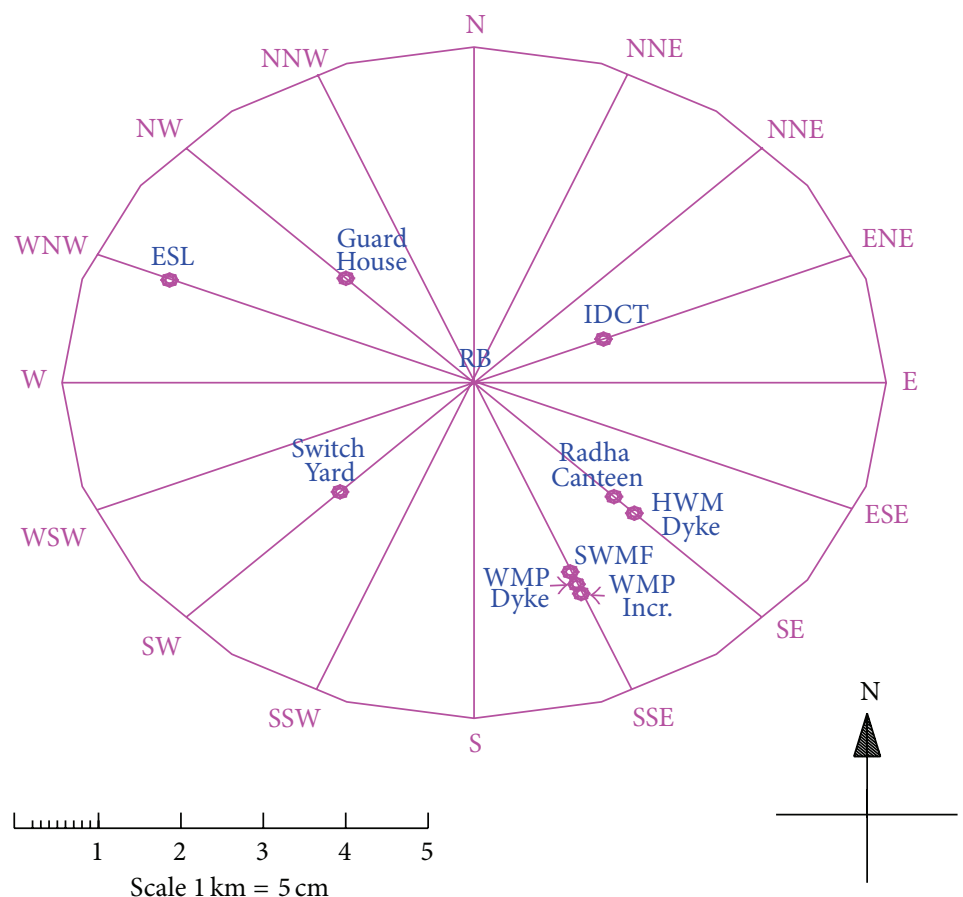

FIGURE 1: Site map with sampling location.

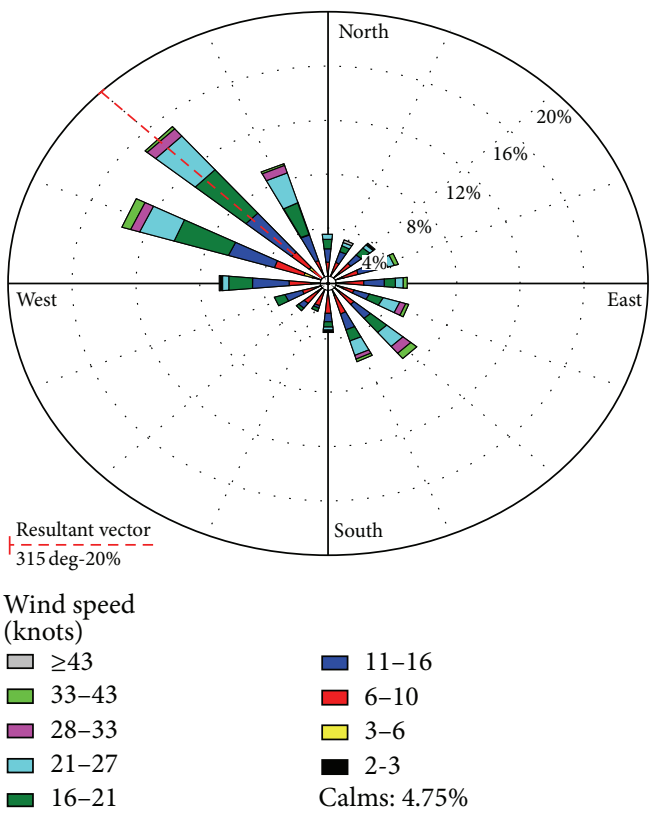

(a)

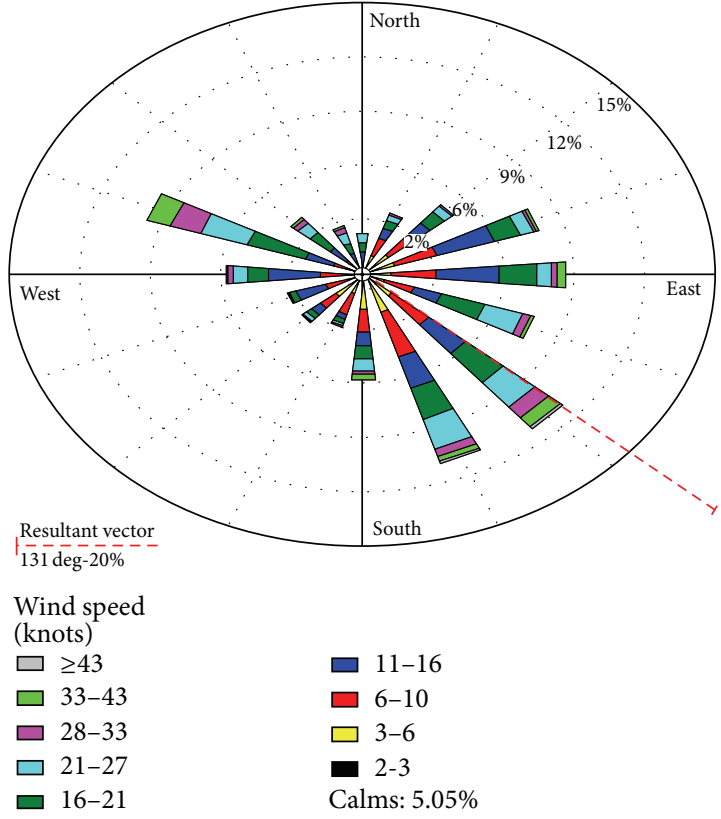

(b)

Figure 2: (a) Wind rose during July-September 2011. (b) Overall wind rose during 2011.

was more important than the rain rate. Higher rain duration with slower rain rate yielded higher ${ }^{3} \mathrm{H}$ concentration in rainwater. This may be due to the extended period available for the scavenging/wash-out process to take effect together with lower dilution. Hence, more ${ }^{3} \mathrm{H}$ will transfer from air moisture to rainwater.
Attanassov and Galeriu [16] reported that the washout process was influenced most significantly by rainfall parameters and air temperature. Different raindrop size distributions cause differences of up to about $70 \%$ in the wash-out outputs; a change of $15^{\circ} \mathrm{C}$ in the air temperature causes an effect of about $50 \%$. More experiments are planned 


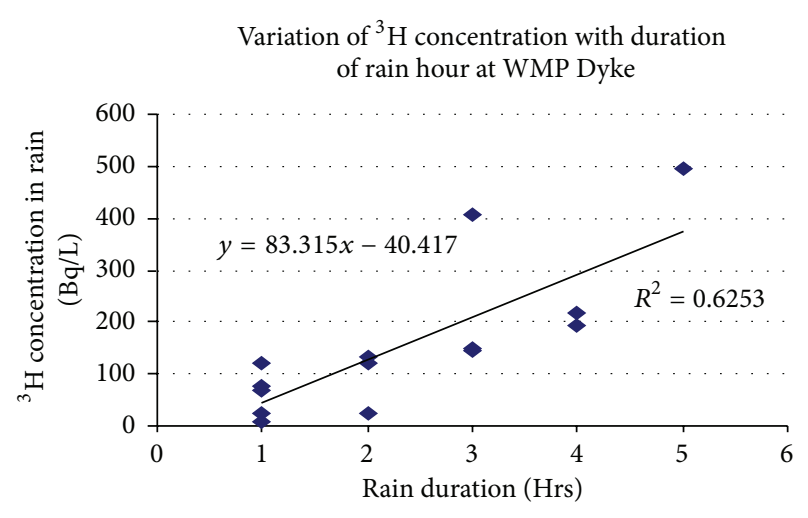

(a)

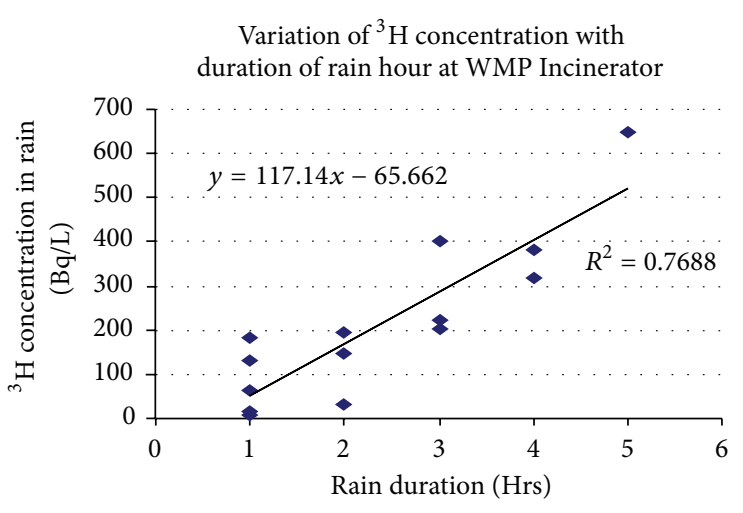

(b)

FIGURE 3: Influence of total rain hours in a day on the rainwater ${ }^{3} \mathrm{H}$ activity.

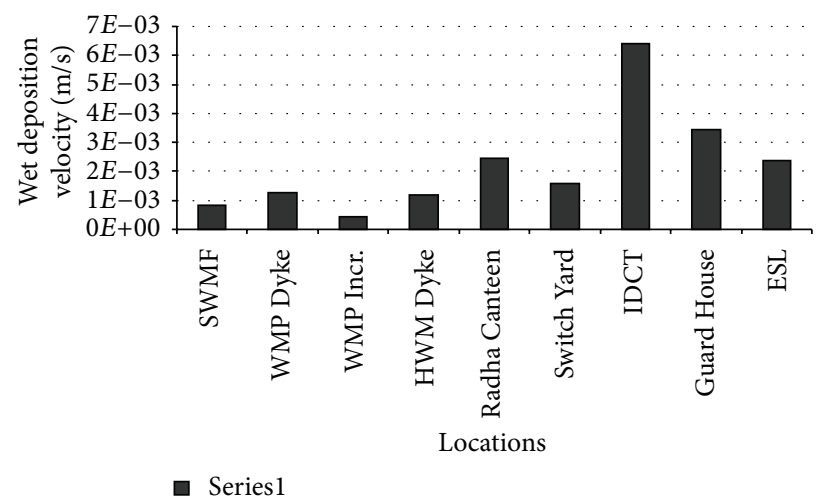

FIgURE 4: Variation of ${ }^{3} \mathrm{H}$ wet deposition velocity around NAPS.

to study the influence of raindrop size distribution and other local meteorological parameters on the wash-out process of ${ }^{3} \mathrm{H}$.

3.3. Estimation of Specific Activity Ratio. The specific activity ratio of tritium between rainwater and air moisture is a measure of scavenging of tritium from air moisture to rainwater. The specific activity ratio, defined as the ratio of specific activity of ${ }^{3} \mathrm{H}$ in rainwater collected at ground level to the specific activity of ${ }^{3} \mathrm{H}$ in air moisture collected at the ground level, is reported in Table 2 . The specific activity ratios estimated at all eight locations within the site boundary of NAPS for each single rain event varied from 0.12 to 1.1. The value 1.1 observed near IDCT may be due to steam release from IDCT.

Belot [5] observed that the scavenging of ${ }^{3} \mathrm{H}$ by rain is a two-stage process: the incorporation of ${ }^{3} \mathrm{H}$ into raindrops from the plume and the reemission of ${ }^{3} \mathrm{H}$ while passing through clean air. The extent of incorporation of ${ }^{3} \mathrm{H}$ into the raindrop depends upon factors such as the drop size distribution, the ambient temperature, and the contact time between the HTO plume and the raindrop.

3.4. Estimation of Wet Deposition Velocity. Table 2 shows that deposition velocity at nine locations for the year 2011 for Narora region is found to be from $4.4 E-04$ to
$6.4 E-03 \mathrm{~m} \cdot \mathrm{s}^{-1}$. The average value for wet deposition velocity $V_{w}$ for NAPS site is estimated as $3.2 E-03 \mathrm{~m} \cdot \mathrm{s}^{-1}$ (Figure 4), which is comparable with the reported value of $1.6 E-03$ by Vogt [17] and 6.6E- 03 by Reji et al. [12].

\section{Conclusions}

The present study makes some progress toward understanding the HTO wash-out process in a tropical region using measurements of the ${ }^{3} \mathrm{H}$ concentration in air moisture and rainwater collected at ground level downwind of an HTO source. The average ${ }^{3} \mathrm{H}$ activity in rainwater increased as the total rain hours in a day increased, and the correlation coefficient of 0.62 to $0.76(P<0.001)$ was estimated for various locations. Higher rain duration with slower rain rate yielded higher ${ }^{3} \mathrm{H}$ concentration as more time was available for the scavenging/wash-out process to take effect together with lower dilution. A variation of 0.12 to 1.13 in the tritiumspecific activity ratio between raindrop and air moisture at ground level was observed with an average of 0.38 .

\section{Acknowledgments}

The authors would like to thank Dr. A. K. Ghosh, Director, Health, Safety and Environment Group (HS\&E group), 
BARC, for his keen interest and encouragement. The continuous support given by Shri. S. K. Sharma, Station Director, NAPS, and Shri. D. S. Choudhary, Chief Superintendent, NAPS, is gratefully acknowledged. Thanks are also due to other colleagues in ESL, NAPS, for their help and cooperation.

\section{References}

[1] B. G. Blaylock, F. O. Hoffman, and M. L. Frank, "Tritium in the aquatic environment," Radiation Protection Dosimetry, vol. 16, no. 1-2, pp. 65-71, 1986.

[2] C. Boyer, L. Vichot, M. Fromm et al., "Tritium in plants: a review of current knowledge," Environmental and Experimental Botany, vol. 67, no. 1, pp. 34-51, 2009.

[3] M. De Bortoli and P. Gaglione, "Variability of wash out ratio for some fallout radionuclides, physical behaviour of radioactive contaminants in the atmosphere," in Proceedings of the Symposium Jointly Organised by IAEA and World Meteorological Organization, pp. 167-180, Vienna, Austria, 1974.

[4] M. Velarde and M. Perlado, "Tritium gas and tritiated water vapour behaviour in the environment from releases into the atmosphere from fusion reactors," Fusion Engineering and Design, vol. 58-59, pp. 1123-1126, 2001.

[5] Y. Belot, "Predicting the wash out of tritiated water from the atmospheric plumes," in Workshop of the IEA Task Group on Tritium Safety and Environmental Effects. AECL, Chalk River, Canada, 1998.

[6] V. Abrol, "Estimation of wash out of tritiated water (HTO) effluent by rain drops," Bulletin of Radiation Protection, vol. 13, pp. 23-26, 1990.

[7] J. M. Hales, Scavenging of Gaseous Tritium Compounds by Rain. BNWL-1659, Battelle, Pacific Northwest Laboratories, Richland, Washington, DC, USA, 1972.

[8] J. M. Hales, "Fundamentals of the theory of gas scavenging by rain," Atmospheric Environment, vol. 6, no. 9, pp. 635-659, 1972.

[9] M. T. Dana, N. A. Wogman, and M. A. Wolf, "Rain scavenging of tritiated water (HTO): a field experiment and theoretical considerations," Atmospheric Environment, vol. 12, no. 6-7, pp. 1523-1529, 1978.

[10] L. F. Belovodski, V. K. Gaevoy, A. V. Golubev, and T. A. Kosheleva, "Tritium oxide wash-out by drops," Journal of Environmental Radioactivity, vol. 36, no. 2-3, pp. 129-139, 1997.

[11] D. P. Nankar, A. K. Patra, P. M. Ravi, C. P. Joshi, A. G. Hegde, and P. K. Sarkar, "Studies on the rain scavenging process of tritium in a tropical site in India," Journal of Environmental Radioactivity, vol. 104, pp. 7-13, 2011.

[12] T. K. Reji, P. M. Ravi, T. L. Ajith, B. N. Dileep, A. G. Hegde, and P. K. Sarkar, "Environmental transport of Tritium and estimation of site-specific model parametres for Kiaga site, India," Radiation Protection Dosimetry, 2011.

[13] Y. P. Gautam, A. K. Sharma, S. Sharma et al., "Monitoring of atmospheric $\mathrm{H}$ around narora atomic power station," Journal of Radioanalytical and Nuclear Chemistry, vol. 285, no. 3, pp. 425430, 2010.

[14] R. E. Faw and J. K. Shultis, "Atmospheric dispersion of radionuclides," in Radiological Assessment: Sources and Doses, p. 465, American Nuclear Society, La Grange Park, Ill, USA, 1999.

[15] N. Miljević, V. Šipka, A. Žujić, and D. Golobočanin, "Tritium around the vinca institute of nuclear sciences," Journal of Environmental Radioactivity, vol. 48, no. 3, pp. 303-315, 2000.
[16] D. Attanassov and D. Galeriu, "Rain scavenging of tritiated water vapour: a numerical Eulerian stationary model," Journal of Environmental Radioactivity, vol. 102, no. 1, pp. 43-52, 2010.

[17] K. J. Vogt, "Models for accessing the environmental exposure by tritium released from nuclear installations," in Proceedings of the IAEA-SM-232/15, pp. 521-534, 1979. 

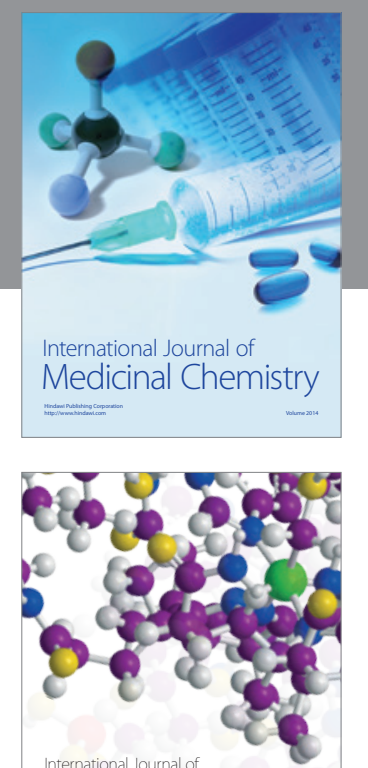

\section{Carbohydrate} Chemistry

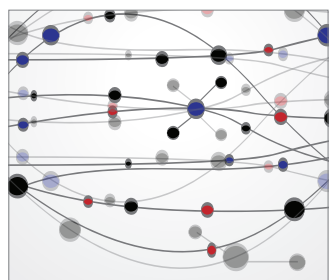

The Scientific World Journal
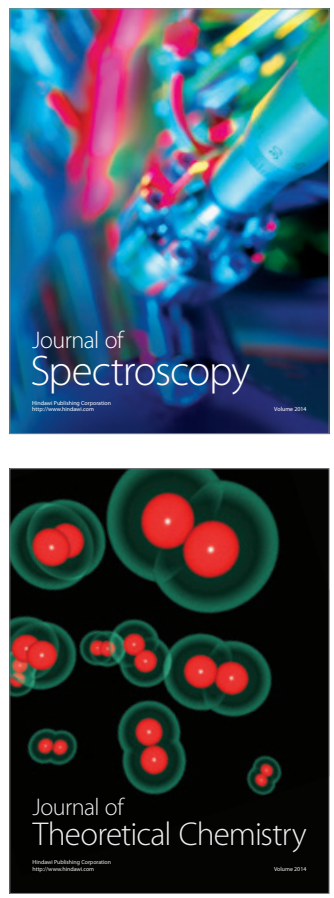
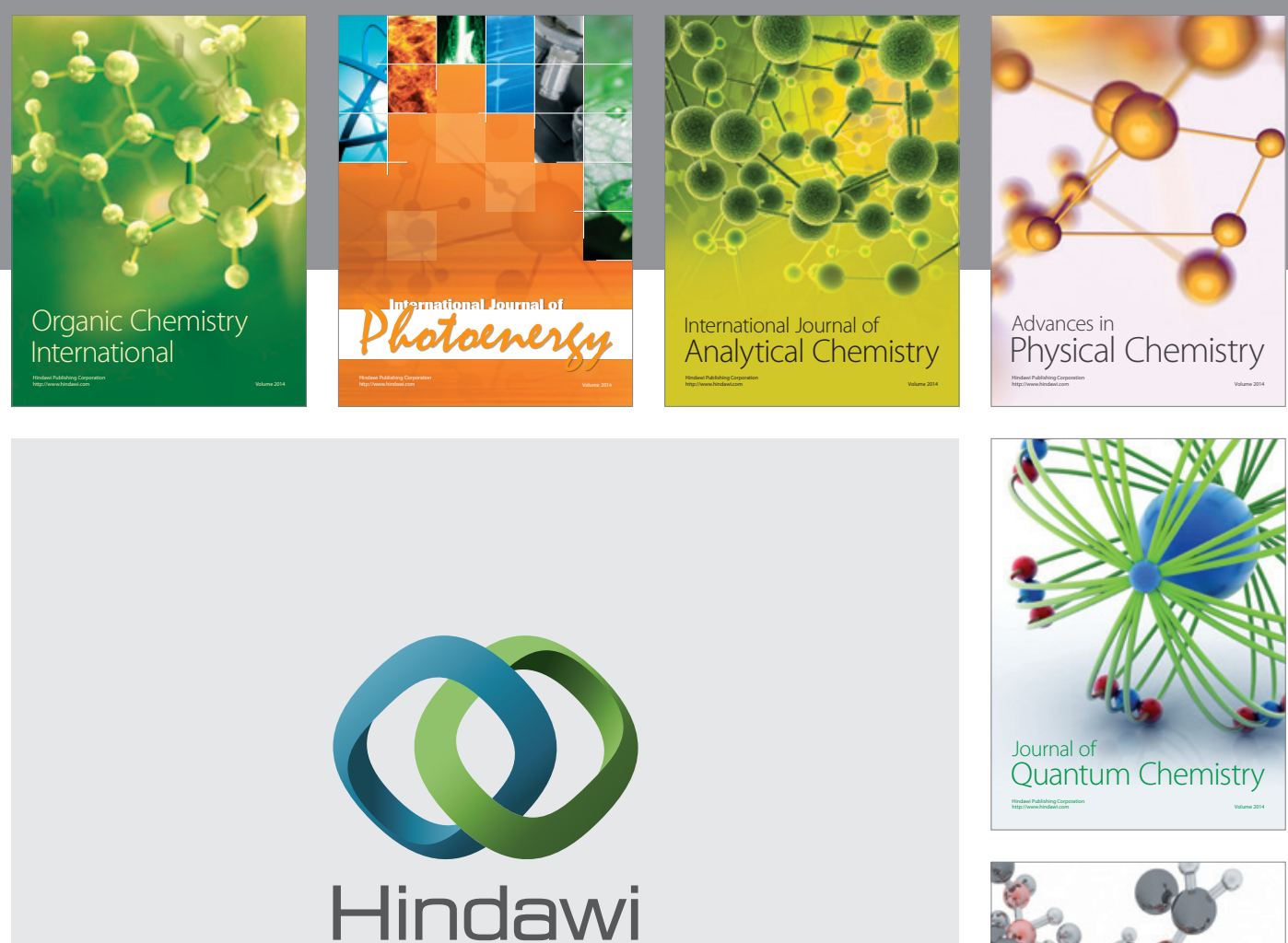

Submit your manuscripts at

http://www.hindawi.com

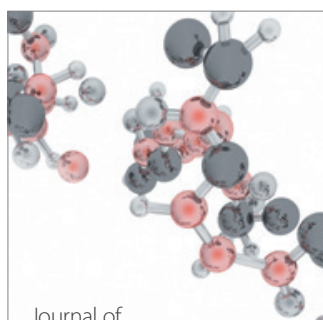

Analytical Methods

in Chemistry

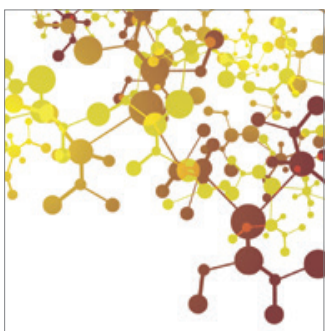

Journal of

Applied Chemistry

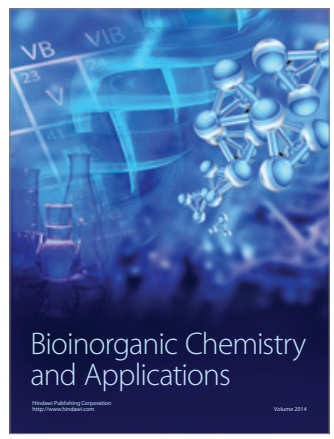

Inorganic Chemistry
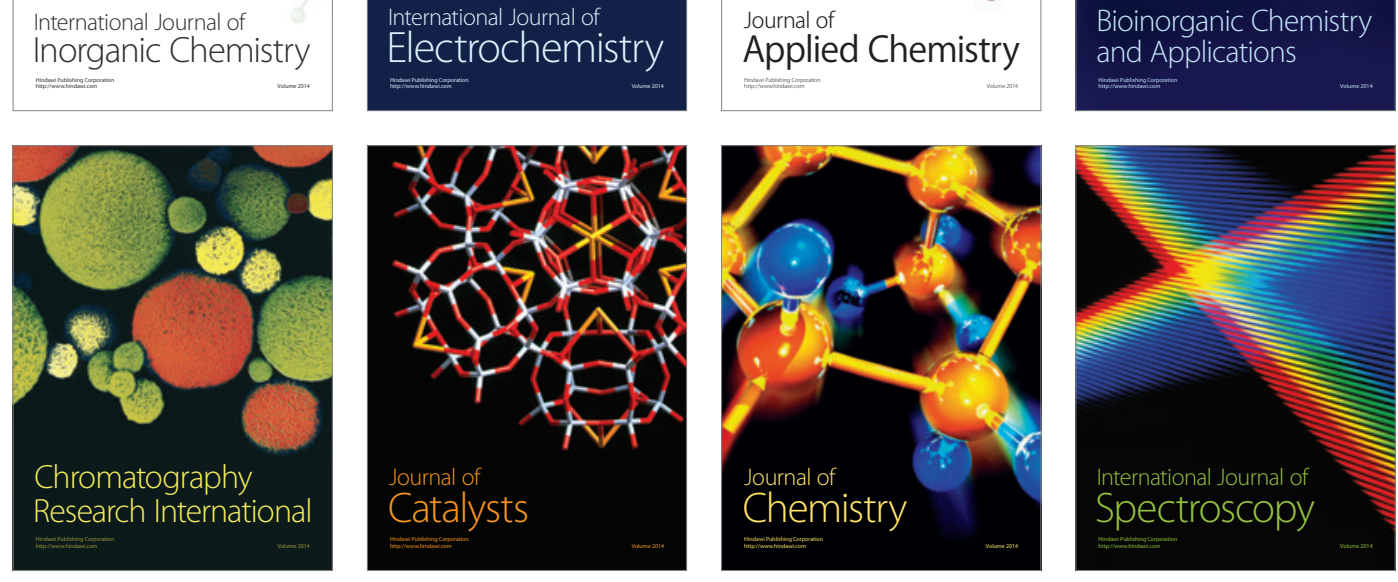